
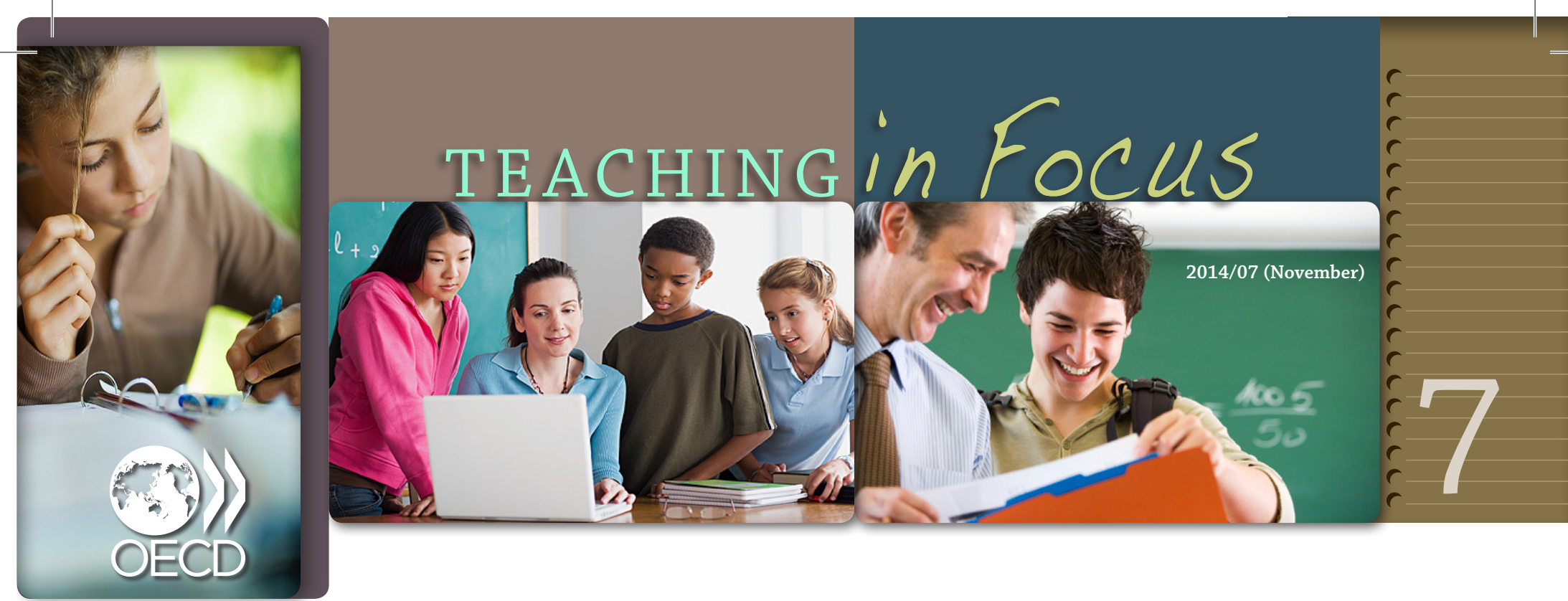

\title{
SCHOOL IMPROVEMENT THROUGH STRONG LEADERSHIP
}

- According to the OECD Teaching and Learning International Survey (TALIS), principals, on average, report frequently engaging in a number of activities that are consistent with instructional leadership. However, this is not the case in every country and large proportions of them report that their training did not include any instructional leadership training or course.

- Although continuous professional development could help fill those gaps, many school leaders report a number of obstacles preventing them from taking part in such learning, including a lack of support and opportunities, and personal and professional obstacles.

\section{What is TALIS?}

TALIS is the first international survey examining teaching and learning environments in schools. It asks teachers and school principals about their work, their schools and their classrooms. This cross-country analysis helps countries identify others facing similar challenges and learn about their policies.

TALIS 2013 focused on lower secondary education teachers and their principals. It sampled 200 schools in more than 30 countries and 20 teachers in each school.

More information available at www.oecd.org/talis.

\section{Leadership activities as the core work of principals}

TALIS asks school principals about how they distribute their time on their day-to-day activities. The work of school leaders is demanding and covers many areas but nearly two-thirds of principals' time, on average, is spent on administrative and leadership activities, and curriculum and teaching. On average, they devote $41 \%$ of their time to administrative and leadership tasks and meetings.

School leaders report often engaging in leadership activities that support the teaching and learning climate of their schools (Figure 1). For instance, principals report taking action to ensure that teachers feel responsible for their students' learning outcomes (76\%) and for improving their teaching skills (69\%). In some countries however, more than half of principals report never, rarely or only sometimes ensuring that teachers take responsibility for improving their teaching skills. This is particularly the case in Finland (60\%), Japan (61\%), Norway (53\%), Sweden (56\%) and Flanders (Belgium) (59\%). Also, school principals often collaborate with teachers to solve 
classroom discipline problems (68\%), again with country variations ranging from $90 \%$ of principals reporting high frequency collaboration in Malaysia and Romania at one end of the spectrum and more than half of principals reporting infrequent collaboration at the other end of the spectrum in Iceland, Japan, the Netherlands and England (United Kingdom). Principals also value their responsibility towards parents or guardians and $65 \%$ of them provide parents with information on the school and student performance. As one would expect, in order to engage effectively in such activities principals need a specific skills set.

Figure $1 \bullet$ Principals' leadership activities

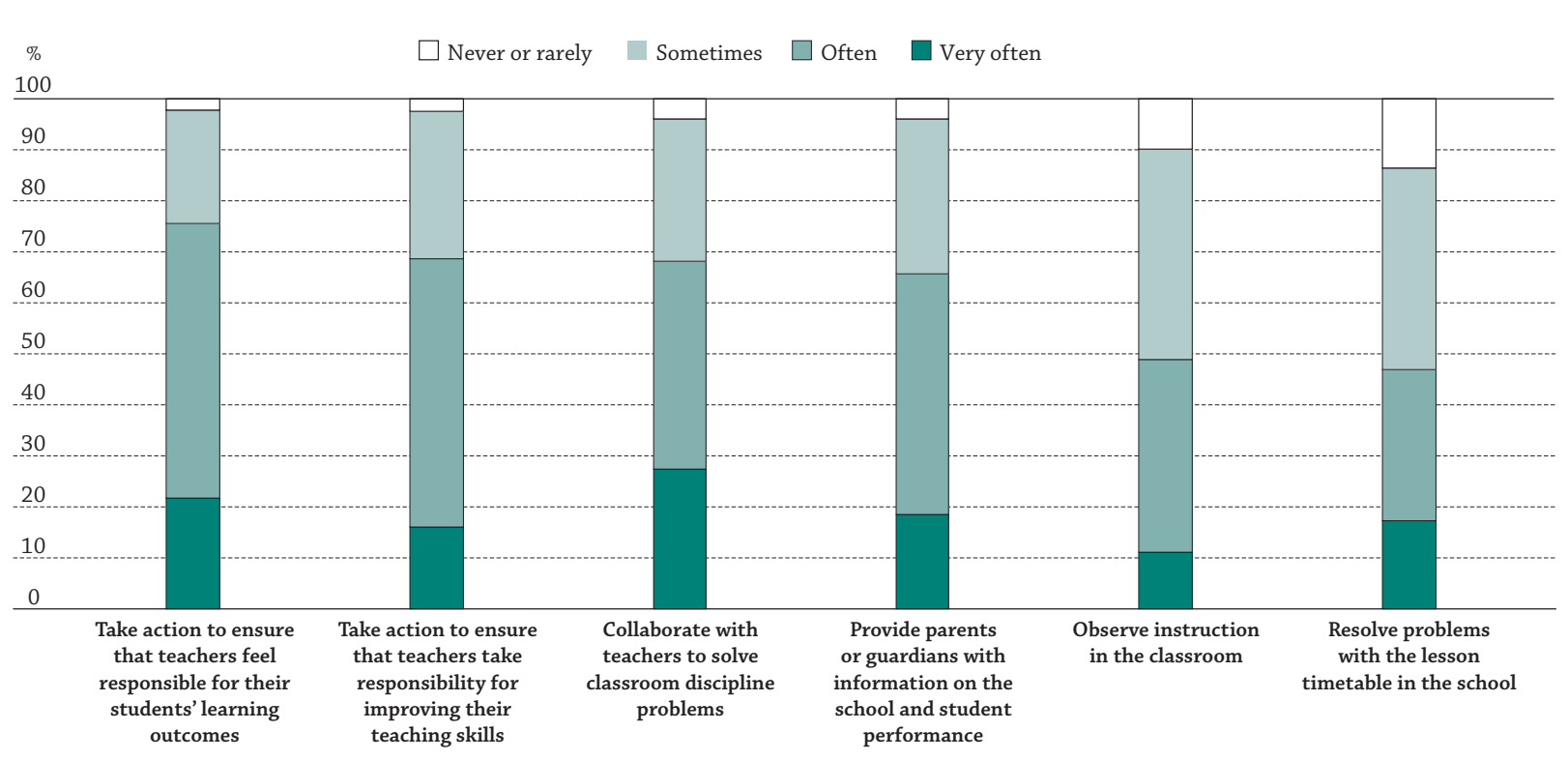

Source: OECD, TALIS 2013 Database.

\section{Instructional leadership as the pillar to effective principal's initial preparation and continuous development}

When looking at their background, it is quite clear that principals are highly educated and experienced professionals. On average across TALIS countries, school principals have 21 years of teaching experience and 9 years of experience in their current role. Apart from teaching, principals bring a variety of other prior experiences to the role, including work in other management roles (on average 6 years) and experience in other jobs. Given the professional experience of the principals and the demands of their jobs, it comes as no surprise that most principals (92\%) have Bachelor's degrees or Master's degrees from universities or equivalent institutions.
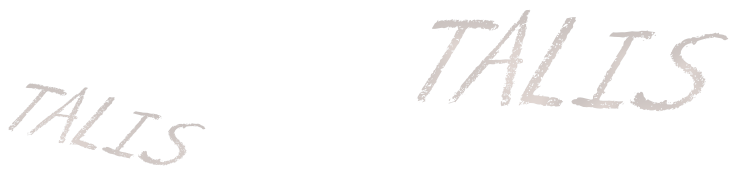
Although one might assume that school leaders' preparation would typically include instructional leadership due to their day-to-day activities, TALIS data suggest that a substantial proportion of principals might not have sufficient specific preparation to take on a school leadership role that focuses on instructional leadership (Figure 2). On average across TALIS countries, only one-quarter of principals report having undertaken preparation in instructional leadership prior to assuming their position, but a similar proportion reports never having received such training (and in some countries, more than half of the principals indicate that they have never had such preparation).

Figure 2 • Elements not included in principals' formal education

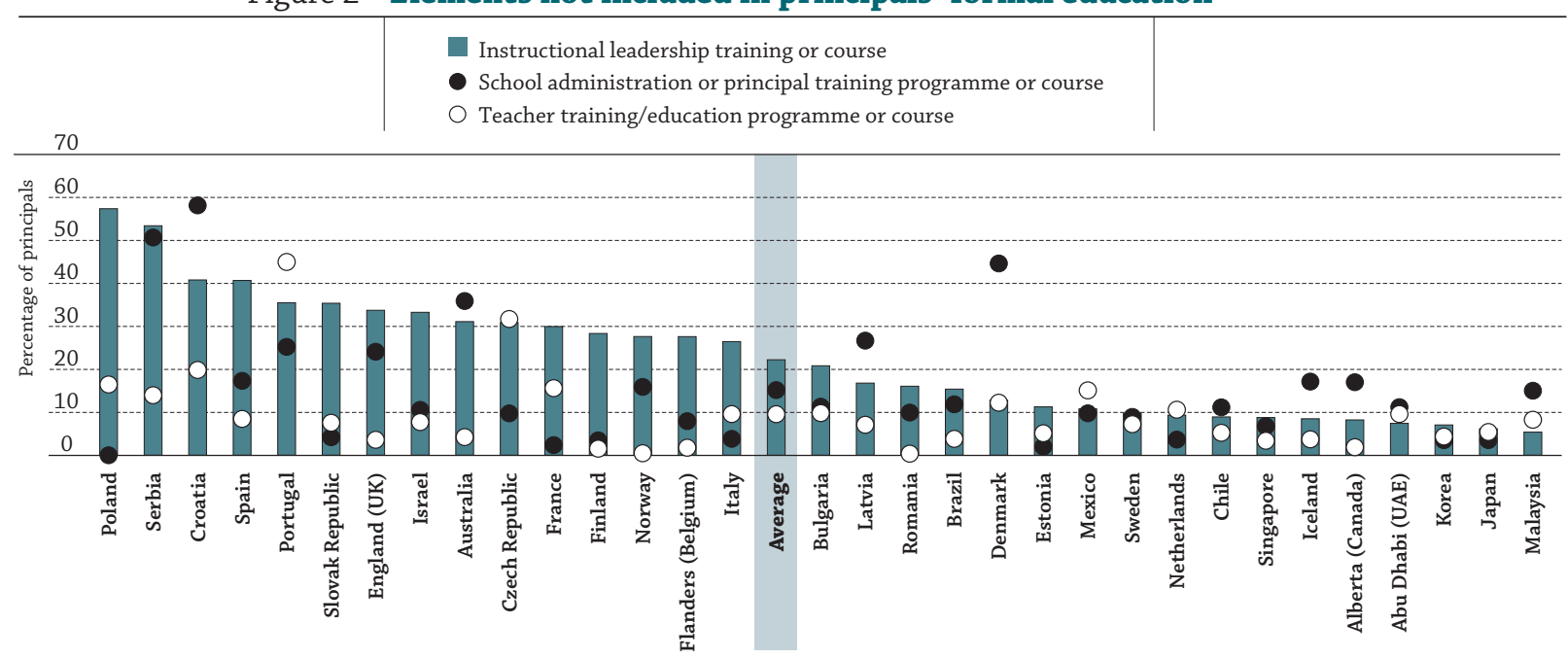

Source: OECD, TALIS 2013 Database.

Continuous professional development is also an important tool for the improvement of principals' skills and thus for school improvement. On average, across TALIS countries, principals spent 20 days participating in a professional network, mentoring or research activity in the 12 months preceding the survey. Similarly, on average, most principals (83\%) report having taken part in courses, conferences or observation visits in other schools. However those participation rates and average number of days vary considerably from one country to the other.
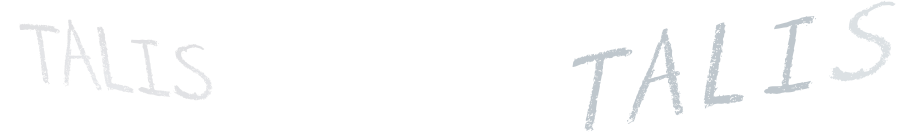

\section{What this means in practice}

TALIS shows that principals might not be getting effective initial preparation to exert their leadership role. Policy makers should include more instructional leadership pre- and in-service training to ensure principals acquire the right skills set before and throughout their career. But school leaders should also seek opportunities to participate in instructional leadership training when already in their role. 


\section{What do school leaders see as the most important barriers for further professional development?}

Even though school leaders recognise their need for further development, they can face challenges preventing their participation in professional development. Among the biggest barriers reported by the principals are: conflicts with their work schedule (43\%), the lack of incentives (35\%), and the high cost of professional development (30\%) (Figure 3). Some of those obstacles can be a real handicap in certain countries. For instance, from $2 \%$ to $82 \%$ of principals report the lack of employer support as a barrier. Moreover, in 13 countries, when it comes to work schedule conflicting with professional development opportunities, more than half of the school leaders report this as a barrier.

Figure 3 • Barriers to principals' participation in further professional development

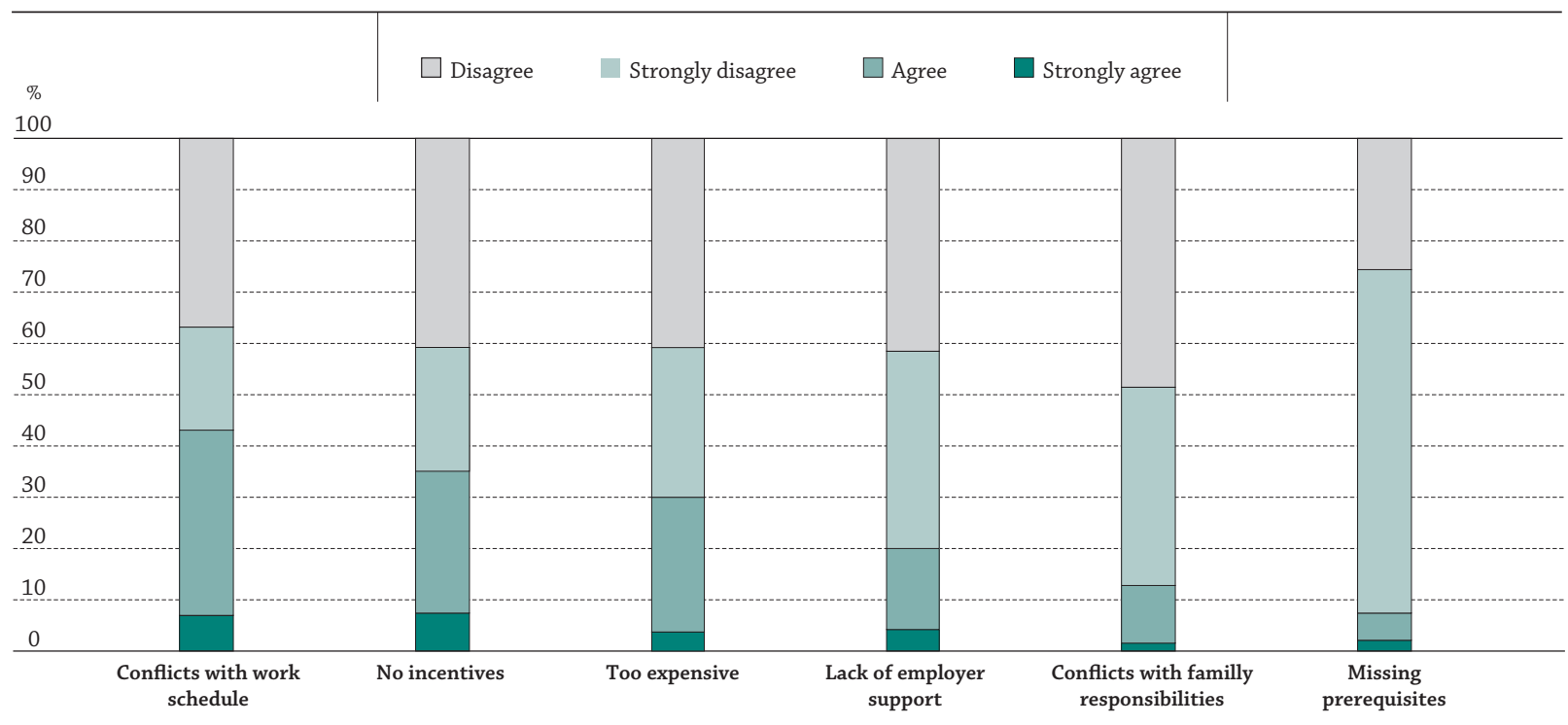

Source: OECD, TALIS 2013 Database.

The bottom line Strong school leadership can greatly facilitate school improvement and student achievement. TALIS shows that many principals report a lack of effective preparation and support to take on a leadership role that is becoming more complex and pedagogical in nature. Therefore more attention should be paid to preparing school leaders effectively. This can be achieved by creating more opportunities for principals' professional development and through removing personal and professional barriers to further learning opportunities.

\section{Visit}

www.oecd.org/talis

Education Indicators in Focus

Pisa in Focus

\section{Contact:}

Katarzyna Kubacka

(katarzyna.kubacka@oecd.org)

Marie-Amélie Doring Serré

(Marie-Amelie.doringserre@oecd.org)
To learn more

OECD (2014), TALIS 2013 Results: An International Perspective on Teaching and Learning, TALIS, OECD Publishing, Paris. OECD (2014), A Teachers' Guide to TALIS 2013, TALIS, OECD Publishing, Paris.

This work is published under the responsibility of the Secretary-General of the OECD. The opinions expressed and arguments employed herein do not necessarily reflect the official views of OECD member countries.

This document and any map included herein are without prejudice to the status of or sovereignty over any territory, to the delimitation of international frontiers and boundaries and to the name of any territory, city or area.

The statistical data for Israel are supplied by and under the responsibility of the relevant Israeli authorities. The use of such data by the OECD is without prejudice to the status of the Golan Heights, East Jerusalem and Israeli settlements in the West Bank under the terms of international law.

You can copy, download or print $\mathrm{OECD}$ content for your own use, and you can include excerpts from $\mathrm{OECD}$ publications, databases and multimedia products in your own documents, presentations, blogs, websites and teaching materials, provided that suitable acknowledgment of $\mathrm{OECD}$ as source and copyright owner is given. All requests for commercial use and translation rights should be submitted to rights@oecd.org. 